\title{
Exergy study on the effect of material parameters and operating conditions on the anode diffusion polarization of the SOFC
}

\author{
Khalid Zouhri $^{1,2} \cdot$ Seong-Young Lee ${ }^{1}$
}

Received: 9 September 2015/Accepted: 23 December 2015/Published online: 22 January 2016

(C) The Author(s) 2016. This article is published with open access at Springerlink.com

\begin{abstract}
In the presented work, a model is created in order to investigate the effect of different material parameters and operating conditions on the anode diffusion overpotential, which influence the exergy and energy efficiency of the solid oxide fuel cell (SOFC). In this research, it was demonstrated that the anode material parameters and operating conditions of the device components such as porosity, tortuosity, pore diameter, temperature, pressure and current density of the anode have various effects on the anode diffusion overpotential, which consequently affect the exergy and energy efficiency of the SOFC. The model has provided a strong direction on how to optimize the SOFC exergy and energy efficiency, by reducing the anode diffusion overpotential, which is affected by various material parameters and operating conditions.
\end{abstract}

Keywords Diffusion polarization - Efficiency · Porosity · Tortuosity $\cdot$ SOFC

\section{List of symbols}

A Area $\left(\mathrm{cm}^{2}\right)$

$A_{\mathrm{f}} \quad$ The thermodynamic factor

$c_{\mathrm{v}} \quad$ The oxygen concentration vacancy

$C_{\text {gas }} \quad$ Capacitance associated the with gas-phase diffusion polarization $\left(\mathrm{F} / \mathrm{cm}^{2}\right)$

$D_{\mathrm{AB}} \quad$ The binary diffusion coefficient $\left(\mathrm{cm}^{2} / \mathrm{s}\right)$

Khalid Zouhri

kzouhri@mtu.edu

1 Department of Mechanical Engineering-Engineering Mechanics, Michigan Technological University, 1400 Townsend Dr., Houghton, MI 49931, USA

2 Department of Mechanical Engineering, University of New Haven, 300 Boston Post Rd., West Haven, CT 06516, USA
$D \quad$ Mass diffusion coefficient $\left(\mathrm{cm}^{2} / \mathrm{s}\right)$

$D_{i, p} \quad$ Knudsen diffusion coefficient of species $\left(\mathrm{cm}^{2} / \mathrm{s}\right)$

$D_{i, j} \quad$ Mutual diffusion coefficient of species $\left(\mathrm{cm}^{2} / \mathrm{s}\right)$

$D_{i, m} \quad$ Mass diffusion coefficient of species in the mixture $\mathrm{m}\left(\mathrm{cm}^{2} / \mathrm{s}\right)$

$D_{v} \quad$ Diffusion coefficient $\left(\mathrm{cm}^{2} / \mathrm{s}\right)$

$E_{\text {act }}$ Activation energy $(\mathrm{J} / \mathrm{mol})$

$E_{o} \quad$ Ideal voltage for hydrogen oxidization (V)

$F \quad$ Faraday's constant $(\mathrm{C} / \mathrm{mol})$

$i \quad$ Cell current $\left(\mathrm{mA} / \mathrm{cm}^{2}\right)$

I Current density $\left(\mathrm{mA} / \mathrm{cm}^{2}\right)$

$i_{\text {o,an }} \quad$ Anode exchange current density $(\mathrm{mA} / \mathrm{cm} 2)$

$i_{\text {o,cat }}$ Cathode exchange current density $(\mathrm{mA} / \mathrm{cm} 2)$

$i_{\text {io }} \quad$ The ion current density $\left(\mathrm{mA} / \mathrm{cm}^{2}\right)$

$i_{\mathrm{el}} \quad$ The electron current density $\left(\mathrm{mA} / \mathrm{cm}^{2}\right)$

$J_{i} \quad$ Transport rate $I\left(\mathrm{~mol} / \mathrm{cm}^{2} \mathrm{~s}\right)$

$j_{\mathrm{H}_{2}} \quad$ The hydrogen flux $\left(\mathrm{mol} / \mathrm{cm}^{2} \mathrm{~s}\right)$

$K_{\text {eq }} \quad$ Equilibrium constant

$L_{\text {ele }} \quad$ Electrolyte thickness $(\mathrm{cm})$

$L_{\text {cat }} \quad$ Cathode thickness $(\mathrm{cm})$

$L_{\mathrm{ba}} \quad$ Anodic diffusion path $(\mathrm{cm})$

LHV Lowe heating value of hydrogen $(\mathrm{kJ} / \mathrm{kg})$

$L_{\mathrm{bc}} \quad$ Cathode diffusion $(\mathrm{cm})$

$L_{\text {an }} \quad$ Anode thickness $(\mathrm{cm})$

$L_{\text {inter }} \quad$ Interconnect thickness $(\mathrm{cm})$

$m \quad$ Activation coefficient

$M \quad$ Molecular weight $(\mathrm{g} / \mathrm{mol})$

$n \quad$ Number of electrons

$n_{f} \quad$ Molar flow rate $(\mathrm{kmol} / \mathrm{s})$

$p \quad$ Partial pressure $(\mathrm{kPa})$

$P \quad$ Pressure $(\mathrm{kPa})$

$\mathrm{Rg} \quad$ Universal gas constant $8.314 \mathrm{~J} / \mathrm{mol} \mathrm{K}$

$R_{\text {gas }} \quad$ The effective resistance $(\Omega)$

$r_{\text {pore }} \quad$ Electrode pore mean radius $(\mathrm{cm})$

$R \quad$ Ohmic resistance $(\Omega)$ 


$\begin{array}{ll}r_{o} & \text { The exchange neutral flux density }\left(\mathrm{mA} / \mathrm{cm}^{2}\right) \\ T & \text { Temperature }(\mathrm{K}) \\ t_{\text {chem }} & \text { Relaxation time }(\mathrm{s}) \\ V_{i} & \text { Molar volume of solute } I\left(\mathrm{~cm}^{2} / \mathrm{mol}\right) \\ V_{\text {Nernst }} & \text { Nernst cell potential }(\mathrm{V}) \\ V_{\text {cell }} & \text { Cell voltage }(\mathrm{V}) \\ W & \text { Work rate }(\mathrm{kW}) \\ X_{i} & \text { Molar fraction of species } \\ x & \text { The distance between electrode and electrolyte } \\ & (\mathrm{cm})\end{array}$

\section{Greek symbol}

$\begin{array}{ll}\alpha_{\text {act }} & \text { The activation transfer coefficient } \\ \sigma_{o} & \text { The interface conductivity } \\ \alpha_{\text {sa }} & \text { The electrode surface area } \\ \alpha_{f} & \text { Constant specific to the exchange current density } \\ \alpha_{b} & \text { Constant specific to the exchange current density } \\ \alpha j & \text { The constant specific to material } j \text { (parameter of } \\ & \text { the ohmic losses) } \\ \beta j & \text { The constant specific to material } j \text { (parameter of } \\ & \text { the ohmic losses) } \\ \beta & \text { The electronic transfer coefficient } \\ \gamma_{\text {cat }} & \text { Pre-exponential coefficient for cathode }\left(\mathrm{mA} / \mathrm{cm}^{2} \text { ) }\right. \\ \gamma_{\text {an }} & \text { Pre-exponential coefficient for anode } \\ \gamma & \text { The reaction order } \\ \delta j & \text { The thickness of the component } j \\ \triangle G_{\text {act }} & \text { The activation energy } \\ \varepsilon & \text { Porosity } \\ \eta_{\text {ohm }} & \text { Ohmic polarization } \\ \eta_{\text {dif }} & \text { Diffusion polarization } \\ \eta_{\text {act }} & \text { Activation polarization } \\ \Pi I & \text { Pi } \\ \rho j & \text { The resistivity of component } j \\ \sigma_{\text {el }} & \text { Electronic conductivity } \\ \sigma_{\text {io }} & \text { Ionic conductivity } \\ \tau & \text { Tortuosity }\end{array}$

$\begin{array}{ll}\text { Subscript } \\ \text { act } & \text { Activation } \\ \text { amb } & \text { Ambient } \\ \text { an } & \text { Anode } \\ c & \text { Air cathode } \\ \text { cat } & \text { Cathode } \\ \text { cv } & \text { Control volume } \\ \text { chem } & \text { Chemical } \\ \text { dif } & \text { Diffusion } \\ \text { ele } & \text { Electrolyte } \\ \text { el } & \text { Electrode } \\ f & \text { Fuel } \\ \text { gas } & \text { Gas } \\ \text { gen } & \text { Generation } \\ \text { io } & \text { Ionic } \\ m & \text { Mixture }\end{array}$

$\begin{array}{ll}\text { ohm } & \text { Ohmic } \\ \text { ox } & \text { The oxidation of hydrogen } \\ \text { tot } & \text { Total } \\ \text { sa } & \text { Surface area } \\ s & \text { Structure }\end{array}$

$\begin{array}{ll}\text { Superscript } \\ \text { ch } & \text { Chemical } \\ b & \text { Bulk } \\ l & \text { Flow at the electrode site } \\ \text { ph } & \text { Physical } \\ r & \text { Flow at the reaction site } \\ \text { reac } & \text { Reacted }\end{array}$

\section{Introduction}

Fuel cells are promising technology that provides high-efficient energy and low emissions. Fuel cells convert stored chemical energy in fuel directly into electricity via electrochemical reaction without combustion. Due to the increase in world energy consumption driven by economic growth and increasing population, as well the realization that fossil fuel sources are limited and relatively high cost, a solid oxide fuel cell (SOFC) can provide clean and efficient energy.

The SOFC operates at high temperature, usually about $\sim 1000{ }^{\circ} \mathrm{C}$, in order to ensure adequate ionic and electronic conductivity. The SOFC can be fed primarily with coal base syngas or natural gas. The first solid-state oxygen ion conductor was discovered by Nernst in 1899 [1]; however, the industrial research in developing the SOFC for application was undertaken since 1958 by Westinghouse Electric Corp [2]. The SOFC has many advantages when compared with other fuel cells such as simple design and construction, and two-phase reaction (gas-solid) instead of three phase reaction (gas-liquid-solid) on molten carbonate fuel cells (MCFCs). The two phases eliminate the problem of corrosion of the cell and the stack component and also eliminates the depletion of the electrolyte that affects the cell performance and lifetime. The advantage of the high operating temperature of the SOFC allows the electrochemical kinetics to process faster without the need of the high-noble metal of the electrode. The mixed conducting oxides have been intensively studied since the early 1980 s as an alternative to noble metals. The SOFC design in both tabular and planar depends highly on the material properties such as the thermochemical and mechanical stability at a high temperature range, as well the compatibilities of the material that compose the cell components in order to keep a good electrical contact across an interface, and avoid mechanical instability due to volume changes or mismatch in thermal expansion coefficients.

The SOFC has three types of losses [3, 4]: ohmic overpotential, activation overpotential, and diffusion 
overpotential. The ohmic polarization is caused by the ionic resistance of the electrolyte, the electric resistance of the electrode, the cell interconnect, and the contact resistance between. The most critical factors governing the ohmic losses in SOFC are the material conductivity, material thickness, and the contact resistance [5]. Activation polarization is the voltage overpotential required to overcome the activation energy of the electrochemical reaction on the catalytic surface. A buildup of charge occurs between the electrode and electrolyte at the three phase boundary (TPB) which caused the activation losses. Diffusion polarization is losses caused by the net transport of material within a single phase in the absence of mixing (by mechanical means or by convection). In this work, the analysis of the effect of material properties and operating conditions variation is performed only on the anode diffusion overpotential.

The most common anode material is Ni/YSZ composite, which still dominates; especially for pure hydrogen fuel; also, the Pt/YSZ has been used as an anode for SOFC [6]. The anode material composite must be porous to allow fuel to flow towards the electrolyte, the YSZ dense layer on nickel helps stop the grain growth of nickel during the electrochemical reactions. The metal materials are purely electronic conductor and YSZ essentially ionic conductor. Under standard operating conditions inside SOFC, the main transport mechanism is found by diffusion. The diffusions occur in nanoporous media, in which the molecules frequently collide with the pore wall. The diffusion with respect to porous electrodes is effected by many factors - such as tortuosity, porosity, time, size, permeability, etc. Fewer results were reported on the activation polarization and ohmic overpotential [7-9]. However, to the best of our knowledge, the effect of material properties on the anode diffusion polarization and its effect on the exergy and energy efficiency have not been presented in the open literature. This is important because the effect of the material parameters, operating condition, and anode geometry has not previously been considered to understand the effect of those factors on anode diffusion polarization and its effect on the energy and exergy efficiency. To this end, this work presents a comprehensive analysis to understand the impact of each factor on the anode diffusion polarization of SOFC. The aim of this paper is to understand the parameters that influence the anode diffusion polarization and how it can be optimized to reduce the SOFC losses and enhance the energy and exergy efficiency.

\section{Electrochemical model}

In the SOFC, a neutral molecule of oxygen takes two electrons from the cathode, conducts through the electrolyte, returns the electrons to the external circuit, and oxidizes the products $\mathrm{H}_{2}$ at the anode surface as described in Fig. 1 .
The general SOFC reaction is $[10,11]$ :

$\mathrm{H}_{2}+\frac{1}{2} \mathrm{O}_{2} \rightarrow \mathrm{H}_{2} \mathrm{O}+$ waste heat + electric energy.

At the porous cathode, the oxygen reduction takes place through Eq. (2).

$\frac{1}{2} \mathrm{O}_{2}+2 e l+V_{o}^{\prime \prime} \rightarrow O_{o}^{\prime \prime}$

For the anode, the electrochemical oxidation for $\mathrm{H}_{2}$ can be expressed by the following:

$\mathrm{H}_{2}+\mathrm{O}^{2-} \rightarrow \mathrm{H}_{2} \mathrm{O}+2 e^{-}$

SOFC current is calculated by the following equation:

$V_{\text {cell }}=V_{\text {Nernst }}-\eta_{\text {ohm }}-\eta_{\text {act }}-\eta_{\text {dif }}$

where $V_{\text {Nernst }}$ is Nernst potential, and $V_{\text {cell }}$ is the cell voltage, which is calculated by the following equation:

$V_{\text {Nernst }}=E^{o}+\frac{R T}{2 F} \ln \left(\frac{X_{\mathrm{H}_{2}}^{b} X_{\mathrm{O}_{2}}^{b}}{X_{\mathrm{H}_{2} \mathrm{O}}^{b}}\right)+0.5 \ln \left(\frac{P_{\mathrm{Cat}}}{P_{\mathrm{amb}}}\right)$

where $E^{\mathrm{o}}$ is the ideal voltage, and it can be calculated with following equation:

$E^{0}=1.2723-2.7645 \times 10^{-4} T_{s}$.

The governing equations for momentum, heat, and mass transport are reported in previous studies [12-14] with boundary conditions at the fuel channel/electrolyte $(\mathrm{FC} / \mathrm{E})$ and cathode/electrolyte $(\mathrm{C} / \mathrm{E})$ interfaces used to solve the mass, energy, and charge transport equations. Using the solved governing equations, the current densities of the anode side for hydrogen and of the cathode side for oxygen reduction can be calculated by the following equations:

$$
\begin{aligned}
I_{c}= & \mathrm{AV}_{e, c} \times \frac{0.25 \times 10^{10} \exp \left(\frac{-130,000}{R T}\right) \cdot R T \sqrt{{p_{O_{2}}}}}{F} \\
\times & {\left[\exp \left(\frac{-2 F \eta_{\mathrm{act}}}{R T}\right)-\exp \left(\frac{2 F \eta_{\mathrm{act}}}{R T}\right)\right] } \\
I_{a, \mathrm{H}_{2}}= & \mathrm{AV}_{e, a} \times \frac{2.1 \times 10^{11} \exp \left(\frac{-120,000}{R T}\right) \cdot \mathrm{RT} \cdot p_{\mathrm{H}_{2} \mathrm{O}}^{0.266}}{F \cdot\left(K_{\mathrm{eq}, \mathrm{H}_{2}} \cdot p_{\mathrm{H}_{2}}\right)^{0.266}} \\
& \times\left[\exp \left(\frac{2 F \eta_{\mathrm{act}, a, \mathrm{H}_{2}}}{R T}\right)-\exp \left(\frac{-2 F \eta_{\mathrm{act}, a, \mathrm{H}_{2}}}{R T}\right)\right] .
\end{aligned}
$$

The electronic conductivities in the cathode and the anode as well the ionic conductivities can be calculated by the following equations:

$$
\begin{aligned}
& \sigma_{\text {io,cathode }}=\frac{4 \cdot 2 \cdot 10^{7}}{T} \exp \left(\frac{-1200}{T}\right) \\
& \sigma_{\text {elelctrolyte }}=33 \cdot 4 \cdot 10^{3} \exp \left(\frac{-10,300}{T}\right)
\end{aligned}
$$


Fig. 1 SOFC schematic with electrochemical equations at the cathode and anode

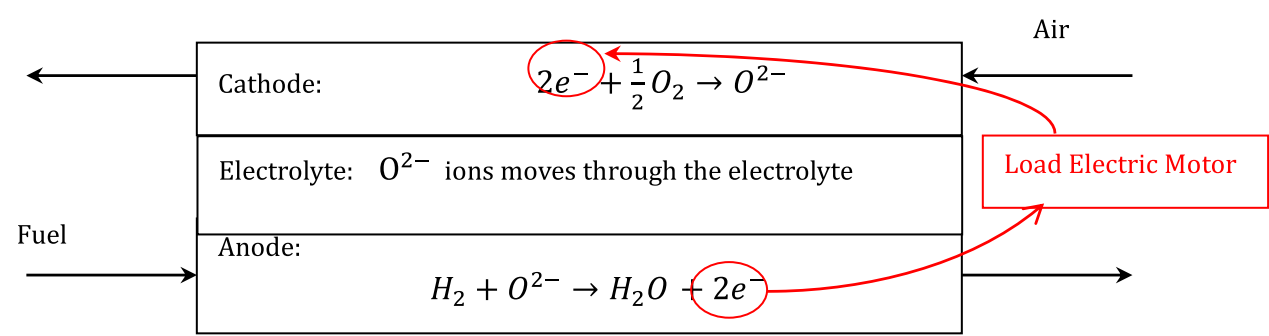

$\sigma_{\text {io,anode }}=\frac{9.5 \times 10^{7}}{T} \exp \left(\frac{-1150}{T}\right)$.

\section{Diffusion polarization}

Diffusion refers to the net transport of material within a single phase in the absence of mixing (by mechanical means or by convection). For the diffusion polarization, it can be stated by the following equations:

$\eta_{\text {dif }}=\eta_{\text {dif }}^{\text {anode }}+\eta_{\text {dif }}^{\text {cathode }}$

$\eta_{\text {dif }}=\frac{R T}{2 F} \ln \left(\frac{X_{\mathrm{H}_{2}}^{b} X_{\mathrm{H}_{2} \mathrm{O}}^{r}}{X_{\mathrm{H}_{2} O}^{b} X_{\mathrm{H}_{2}}^{r}}\right)+\frac{R T}{2 F} \ln \left(\frac{X_{\mathrm{O}_{2}}^{b}}{X_{\mathrm{O}_{2}}^{r}}\right)$.

The concentration gradient and hydrogen flux due to the hydrogen reaction can be calculated as follows:

$J_{\mathrm{H}_{2}}=-\frac{P_{\mathrm{an}} D}{R T} \frac{\mathrm{d} X_{\mathrm{H}_{2}}}{\mathrm{~d} r}+X_{\mathrm{H}_{2}} J_{\mathrm{tot}}$.

\section{Anode diffusion polarization}

By integrating Eq. (14) along the anode length, the following equation is obtained for hydrogen and steam molar fraction:

$D_{\mathrm{H}_{2}, m}=\frac{1-X_{\mathrm{H}_{2}}}{\sum_{i} D_{\mathrm{H}_{2}, i}}$.

When fluid transport through a network of fluid-filled pores inside the particles provides access for solute absorption sites, the diffusion flux can be expressed in terms of a pore diffusion coefficient. The diffusion coefficient can be expressed as follows:

$X_{\mathrm{H}_{2}}^{r}=X_{\mathrm{H}_{2}}^{1}-\frac{i R T_{f} L_{\mathrm{an}}}{2 F P_{\mathrm{an}} D_{\mathrm{H}_{2}, \mathrm{p}}}$

$X_{\mathrm{H}_{2} \mathrm{O}}^{r}=X_{\mathrm{H}_{2} \mathrm{O}}^{1}-\frac{i R T_{f} L_{\mathrm{an}}}{2 F P_{\mathrm{an}} D_{\mathrm{H}_{2} \mathrm{O}, \mathrm{p}}}$.

$D_{\mathrm{H}_{2}, i}$ is the mutual diffusion coefficient, and it refers to the diffusion of hydrogen in a mixture. The mutual diffusion coefficient indicates that the flux of a diffusing component is proportional to the concentration gradient. The diffusion is affected by other factors beside the gradient in concentration such as the intermolecular interactions of molecules [15-17]. In this analysis, we only considered the diffusion that is caused by the concentration gradients and can be estimated by the following equation:

$$
D_{\mathrm{H}_{2}, i}=\frac{0.00143 T_{f}^{1.75}}{P_{\mathrm{an}} M_{\mathrm{H}_{2}}^{0.50}\left(v_{\mathrm{H}_{2}}^{1 / 3}+v_{i}^{1 / 3}\right)^{2}} .
$$

Since the hydrogen flow is opposite and equal to steam flux, we can write the following equation:

$J_{\text {tot }}=J_{\mathrm{H}_{2}}+J_{\mathrm{H}_{2} \mathrm{O}}=0$

$J_{\mathrm{H}_{2}}=\frac{i}{2 F}$.

Also we have:

$\int_{X_{\mathrm{H}_{2}}^{b}}^{X_{\mathrm{H}_{2}}^{1}} \mathrm{~d} X_{H_{2}}=\int_{0}^{L_{b a}}-\frac{i R T_{f}}{2 F P_{\mathrm{an}} D_{\mathrm{H}_{2}, m}} \mathrm{~d} r$.

And this differentiate equation yields the hydrogen molar concentration at the anode surface as expressed by the following:

$X_{\mathrm{H}_{2}}^{1}=X_{\mathrm{H}_{2}}^{b}-\frac{i R T_{f} L_{b a}}{2 F P_{\mathrm{an}} D_{\mathrm{H}_{2}, m}}$.

The steam diffusion, can be stated as follows:

$X_{\mathrm{H}_{2} \mathrm{O}}^{1}=X_{\mathrm{H}_{2} \mathrm{O}}^{b}-\frac{i R T_{f} L_{b a}}{2 F P_{\mathrm{an}} D_{\mathrm{H}_{2} \mathrm{O}, m}}$.

In the anode, the fluid transport through a network of fluid-filled pores inside the particles provides access for solute absorption sites. The pore diffusion coefficient of this access can be calculated by the following equation:

$D_{\mathrm{H}_{2}, \mathrm{p}}=\frac{\varepsilon}{\tau}\left[\frac{3}{4 r_{\mathrm{por}}}\left(\frac{\prod}{2 R T_{s}}\right)^{0.5}+\frac{1}{D_{\mathrm{H}_{2} \mathrm{o}, \mathrm{m}}}\right]$,

where $\varepsilon$ and $\tau$ are the porosity and tortuosity of the anode, respectively. The porosity is a measure of the empty spaces in a material, and is calculated by the volume of emptiness over the total volume; its value is between 0 and $100 \%$. The tortuosity is a property of curves being tortuous and it can be calculated with arc-chord ratio, which is the ratio of the length of the curve to the distance between the ends of it. 


\section{Cathode diffusion polarization}

The cathode diffusion coefficient is caused by the transport that occurs within the fluid phase contained inside the particle. Using the same method as described above for the anode, the oxygen flow can be calculated by the following equation:

$J_{\mathrm{O}_{2}}=-\frac{P_{\mathrm{cat}} D}{R T} \frac{\mathrm{d} X_{\mathrm{O}_{2}}}{\mathrm{~d} r}+X_{\mathrm{O}_{2}} J_{\text {tot }}$

and the mutual diffusion coefficient for oxygen into air is stated as follows:

$D_{\mathrm{O}_{2}, \mathrm{~N}_{2}}=\frac{0.00143 T_{c}^{1.75}}{P_{\mathrm{an}} M_{\mathrm{O}_{2}, \mathrm{~N}_{2}}^{0.5}\left(v_{\mathrm{O}_{2}}^{1 / 3}+v_{\mathrm{N}_{2}}^{1 / 3}\right)^{2}}$.

The solute concentration is generally similar in magnitude to the external fluid concentration. A solute molecule transported by pore diffusion may attach to the sorbent and detach many times along its path. Equation (25) is integrated using the following boundary conditions:

$J_{\text {tot }}=J_{\mathrm{O}_{2}}=\frac{i}{4 F}$

$L_{b c}=r_{\text {cat }}-r_{T}$.

Solving the differentiate Eq. (29) yields the oxygen fraction at the cathode surface Eq. (30):

$$
\begin{gathered}
\int_{X_{\mathrm{O}_{2}}^{b}}^{X_{\mathrm{O}_{2}}^{1}} \frac{\mathrm{d} X_{\mathrm{O}_{2}}}{X_{\mathrm{O}_{2}}-1}=\int_{0}^{L_{b c}}-\frac{i R T_{c}}{4 F P_{\mathrm{cat}} D_{\mathrm{O}_{2}, \mathrm{~N}_{2}}} \mathrm{~d} r \\
X_{\mathrm{O}_{2}}^{1}=1+\left(X_{\mathrm{O}_{2}}^{b}-1\right) \exp \left(\frac{R T_{c} L_{b c} i}{4 F P_{\mathrm{cat}} D_{\mathrm{O}_{2}, \mathrm{~N}_{2}}}\right) .
\end{gathered}
$$

The molecular mean free path may be larger than the pore diameter, especially for the gas-phase diffusion in small pores at low pressure, which gives rise to Knudsen diffusion. Based on [18], the diffusion through the porous cathode can be calculated as follows:

$D_{\mathrm{O}_{2}, \mathrm{p}}=\frac{\varepsilon}{\tau}\left[\frac{3}{4 r_{\mathrm{por}}}\left(\frac{\prod M_{\mathrm{O}_{2}}}{2 R T_{s}}\right)^{0.5}+\frac{1}{D_{\mathrm{O}_{2}, \mathrm{~N}_{2}}}\right]$.

And the oxygen fraction can be expressed in terms of temperature, pressure, and oxygen diffusion coefficient at cell reaction and is calculated by the following:

$X_{\mathrm{O}_{2}}^{r}=1+\left(X_{\mathrm{O}_{2}}^{1}-1\right) \exp \left(\frac{R T_{s} L_{\mathrm{cat}} i}{4 F P_{\mathrm{cat}} D_{\mathrm{O}_{2}, \mathrm{p}}}\right)$.

\section{Exergy analysis}

The exergy is the maximum possible work of a system as it undergoes a reversible process from the specified initial state to the state of its environment, that is, the dead state. The exergy balance can be described as follows [19]:

$\sum\left(1-\frac{T_{o}}{T}\right) \dot{Q}_{\mathrm{cv}}-\dot{W}_{\mathrm{cv}}+\sum_{\text {in }} \dot{n}_{i} \mathrm{ex}_{i}-\sum_{\text {out }} \dot{n}_{i} \mathrm{ex}_{i}-\dot{\mathrm{Ex}} \mathrm{x}_{d}$
$\quad=0$.

The exergy associated with a material flow can be calculated as follows:

$\dot{\mathrm{Ex}}=\dot{\mathrm{E}} \mathrm{x}^{\mathrm{ph}}+\dot{\mathrm{E}} \mathrm{x}^{\mathrm{ch}}$,

where $\dot{\mathrm{Ex}}{ }^{\text {ph }}$ is the physical exergy and $\dot{\mathrm{Ex}}{ }^{\mathrm{ch}}$ is the chemical exergy, and they can be expressed as follows:

$\dot{\mathrm{Ex}}^{\mathrm{ph}}=\sum_{i} \dot{n}_{i}\left(\left(\bar{h}_{i}-\bar{h}_{o}\right)\right)-T_{o}\left(\left(\bar{s}_{i}-\bar{s}_{i}\right)\right)$

$\mathrm{Ex}^{\mathrm{ch}}=\dot{n} \sum_{i} y_{i}{\overline{\mathrm{ch}_{i}}}^{\mathrm{ch}, o}+\overline{R T}_{o} \sum_{i} y_{i} \ln y_{i}$

where $\overline{\operatorname{ex}}_{i}^{\text {ch,o }}$ is the standard chemical exergy, $\bar{s}$ is the entropy, and $\bar{h}$ is the enthalpy.

The exergy destruction in SOFC can be calculated as follows [20]:

$\dot{\mathrm{Ex}}{ }_{d}=T_{o} \cdot S_{\mathrm{gen}}$,

where $T_{o}$ is the reference temperature and $S_{\mathrm{gen}}$ is the entropy generation.

The exergy efficiency of the SOFC can be calculated by the total exergy product and exergy fuel of device as follows [19, 21]:

$\psi=\frac{\dot{\mathrm{Ex}}}{\dot{\mathrm{E}} \mathrm{x}_{\text {fuel }}}$,

where $\dot{E} x_{\text {product }}$ is the sum of electricity and exergy of the useful heat, and $\dot{E} x_{\text {fuel }}$ is the exergy of hydrogen supplied to the SOFC.

Detailed relations for energy analysis and energy efficiency of the SOFC are reported in Refs. [22-26]. These relations are not mentioned in this paper to have a brief note. The energy efficiency of the SOFC can be calculated by the ratio of generated power to the lower heating value of the hydrogen fuel as follows:

$\eta=\frac{\dot{W}}{n_{f} \cdot \mathrm{LHV}}$.

The model input parameters are listed in Table 1 and in "Appendix" (the ohmic and activation polarization equations and input parameters). 
Table 1 The SOFC model input parameters

\begin{tabular}{ll}
\hline Model input parameters & \\
\hline Cathode thickness $(\mathrm{cm})$ & 0.2 \\
Anode thickness $(\mathrm{cm})$ & 0.015 \\
Interconnect thickness $(\mathrm{cm})$ & 0.01 \\
Electrolyte thickness $(\mathrm{cm})$ & 0.004 \\
Cathode-specific resistivity $(\Omega \mathrm{m})$ & $8.1 \times 10^{-5} \exp \left(600 / T_{s}\right)[27]$ \\
Anode-specific resistivity $(\Omega \mathrm{m})$ & $2.98 \times 10^{-5} \exp \left(-1392 / T_{s}\right)[17]$ \\
Interconnect-specific resistivity $(\Omega \mathrm{m})$ & $0.025[16,28]$ \\
Electrolyte-specific resistivity $(\Omega \mathrm{m})$ & $2.94 \times 10^{-5} \exp \left(10,350 / T_{s}\right)[17]$ \\
Cathode conductivity $(\mathrm{W} / \mathrm{m} \mathrm{K})$ & 2 \\
Anode conductivity $(\mathrm{W} / \mathrm{m} \mathrm{K})$ & 2 \\
Electrolyte conductivity $(\mathrm{W} / \mathrm{m} \mathrm{K})$ & 2 \\
Air injection tube conductivity $(\mathrm{W} / \mathrm{m} \mathrm{K})$ & $-0.0096 \times T+17.892[29]$ \\
\hline
\end{tabular}

\section{Results and discussion}

The model has been developed to simulate the effect of material parameters and operating conditions on the anode diffusion polarization and their effect on the SOFC tabular performance. The model generates cell efficiency, cell voltage, current output, and cell voltage losses (ohmic overpotential, activation overpotential and concentration overpotential). The chemical concentration profiles and other SOFC performance parameters such as the exergy and energy efficiencies are also calculated. The created model of the SOFC is divided into a number of units axially; for each unit thermal equations and the electrochemical are progressively solved with an iterative approach. The model analysis for the anode diffusion polarization of SOFC is calculated with following assumptions:

- The model is based on steady state and fed $100 \%$ with pure hydrogen as fuel, with no reaction gas crossover or side reactions.

- Laminar gas flow in the air channel.

- Non-isothermal operation.

- Ideal gas law is applied.

- The gas velocity is uniform through the fuel channel.

- The SOFC is fed with $100 \%$ pure hydrogen.

- Along the cell axis, the cell voltage is uniform.

- Stationary conditions.

- Heat exchange by radiation is negligible.

\section{Effect of anode porosity and tortuosity}

In this work, we analyze the effect of anode porosity on anode diffusion polarization and its reflection on the SOFC exergy efficiency. Figure 2 (top) shows the effect of porosity on the anode diffusion polarization at different current densities. The increase of current density produced by movement of charged species is dependent on partial pressures of oxygen and water. It can be also seen from Fig. 2 (top) that an increase of current density and decrease of porosity increase the anode diffusion polarization. At the porosity of 0.3 and current density of $600 \mathrm{~mA} / \mathrm{cm}^{2}$ the anode diffusion loss was found to be $0.008 \mathrm{~V}$. The effect of elevated current density increased the anode diffusion polarization, which was expected due to the enhancement of the chemical reaction that occurs at the anode side at high current density and which is reflected on the performance of the SOFC due to the rises of anode diffusion polarization. The anode tortuosity is another property that affects the diffusion polarization, in Fig. 2 (bottom) the maximum anode diffusion polarization was $0.014 \mathrm{~V}$ at $1000 \mathrm{~mA} / \mathrm{cm}^{2}$, and it was observed that an increase of current density with higher tortuosity increases the anode diffusion polarization. At a tortuosity of 5 and a current density of $600 \mathrm{~mA} / \mathrm{cm}^{2}$, the anode diffusion loss is $0.09 \mathrm{~V}$. The increase of anode tortuosity caused a barrier that negatively impacted the electrochemical reaction that occurs at the anode side and that caused the voltage to drop due to the increase of anode diffusion polarization.

Figure 3 (top) shows the effect of both the anode porosity and tortuosity on the anode diffusion polarization. At the porosity of 0.4 and tortuosity of 1.5 , the anode diffusion polarization is $0.005 \mathrm{~V}$, and this voltage loss increased with increases of both parameters. The results demonstrate that an anode with a continuous porosity gradient improves the anode diffusion of the fuel gas and enlarges electrochemical active at TPB.

The anode diffusion coefficient is defined as the proportionality between the molar flux due to molecular diffusion and the gradient in the concentration of the species. In Fig. 3 (bottom), the increase in pore diameter from 0.0002 to $0.001 \mathrm{~cm}$ increases the anode diffusion coefficient which caused the anode diffusion polarization to drop, and this is due to the larger pore sizes in the anode 

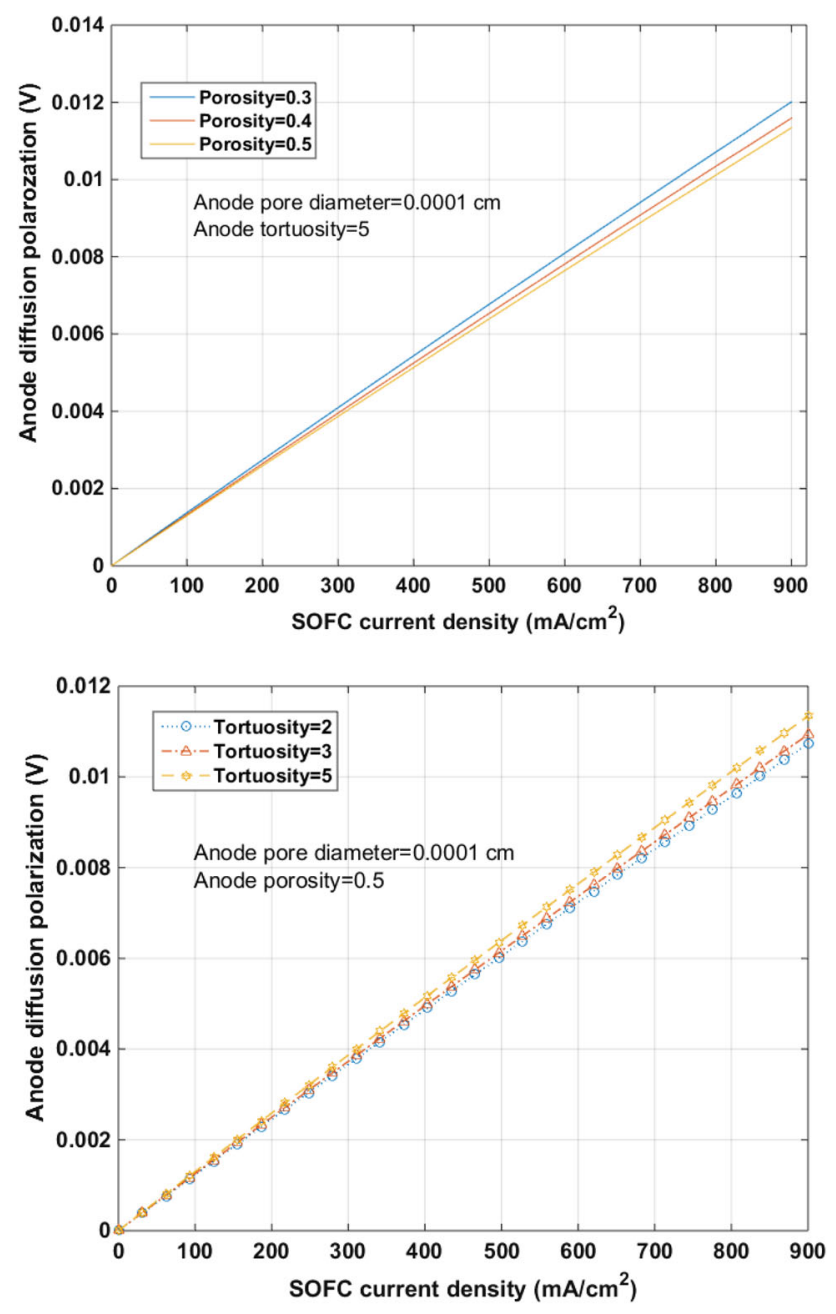

Fig. 2 The effect of current density on the anode diffusion polarization at different porosity (top) and at different tortuosity (bottom)

substrate, which provides more fuel gas channels. Increasing the anode porosity decreases the mass-transfer resistance, which can significantly decrease the electrochemical active region and which results in an increase of the anode diffusion polarization. This result demonstrates that the anode porosity and tortuosity have substantial effect on the anode diffusion overpotential, which consequently affects the exergy efficiency of the SOFC.

In Fig. 4, the exergy efficiency of the cell decreases with an increase of current density. This increase is due to the increased diffusion coefficients and is reflected in the anode diffusion polarization. With a rise of diffusivity, hydrogen molecules reach reaction sites faster. Hence, a decrease in the mass transport losses enhances the performance of the cell. In Fig. 4, the exergy efficiency increases with the increase of porosity and decrease with an increase of tortuosity. A similar result is reported in Fig. 5 concerning the effect of porosity and tortuosity on exergy efficiency at different anode diffusion polarizations. From
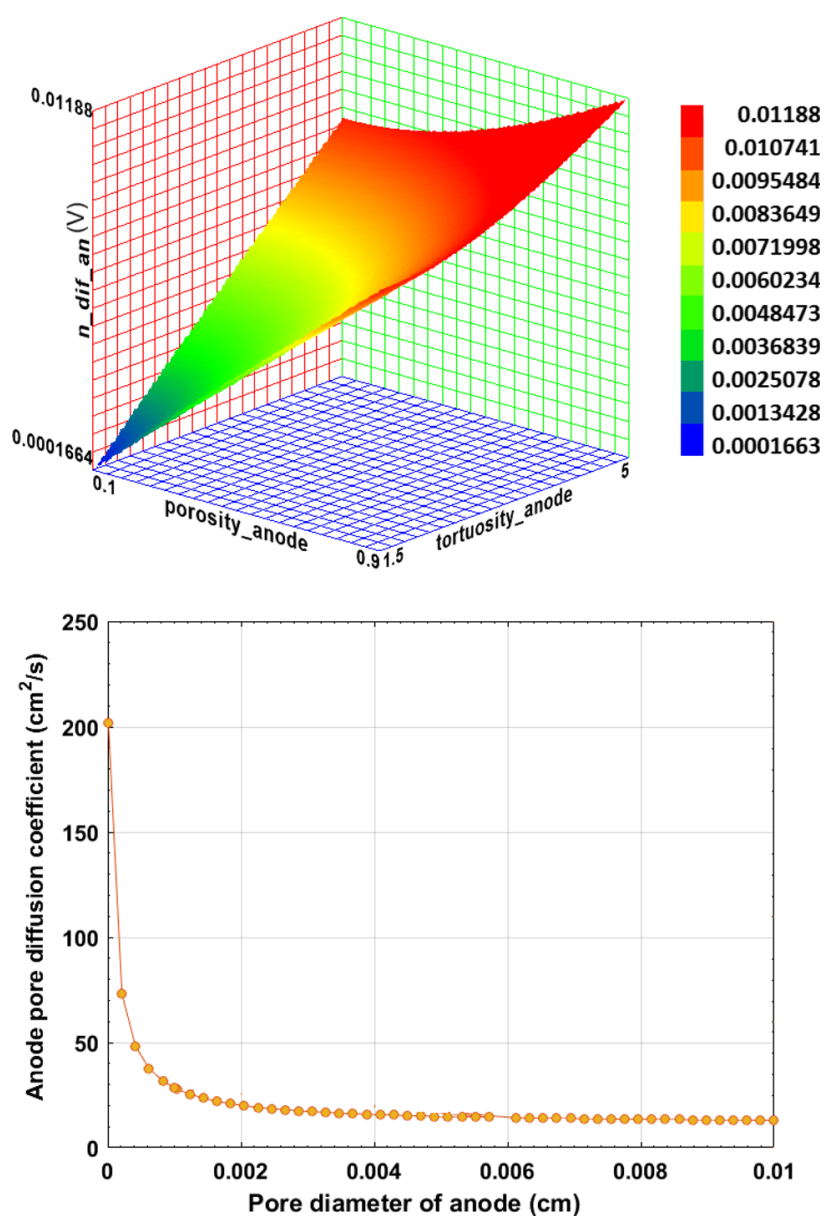

Fig. 3 The effect of porosity and tortuosity on the anode diffusion polarization (top). The effect of pore diameter of anode on the anode pore diffusion coefficient (bottom)

this section analysis, we conclude that increasing the porosity from 0.4 to 0.5 decreases the anode diffusion polarization which caused the exergy efficiency to increase and decreasing the tortuosity from 5 to 2 decreases the anode diffusion polarization which caused the exergy efficiency to increase.

\section{Effects of temperature and pressure}

Figure 6 (top) shows that a rise in temperature and decrease of anode porosity raises the anode pore diffusion coefficient. This result can be seen in that at a temperature of $1200 \mathrm{~K}$ and porosity of 0.3 , the pore diffusion coefficient is $0.005 \mathrm{~cm}^{2} / \mathrm{s}$. The porosity increase from 0.4 to 0.5 leads to an increase of diffusion of species at the anode side, which causes an improvement of electrochemical reaction that occurs at TPB and which was experimentally verified by Ren et al. [30]. When they found that increase of porosity enhances the adequate mass transport at the anode side, however, they did not analyze the effect of porosity on diffusion polarization and its effect on the 

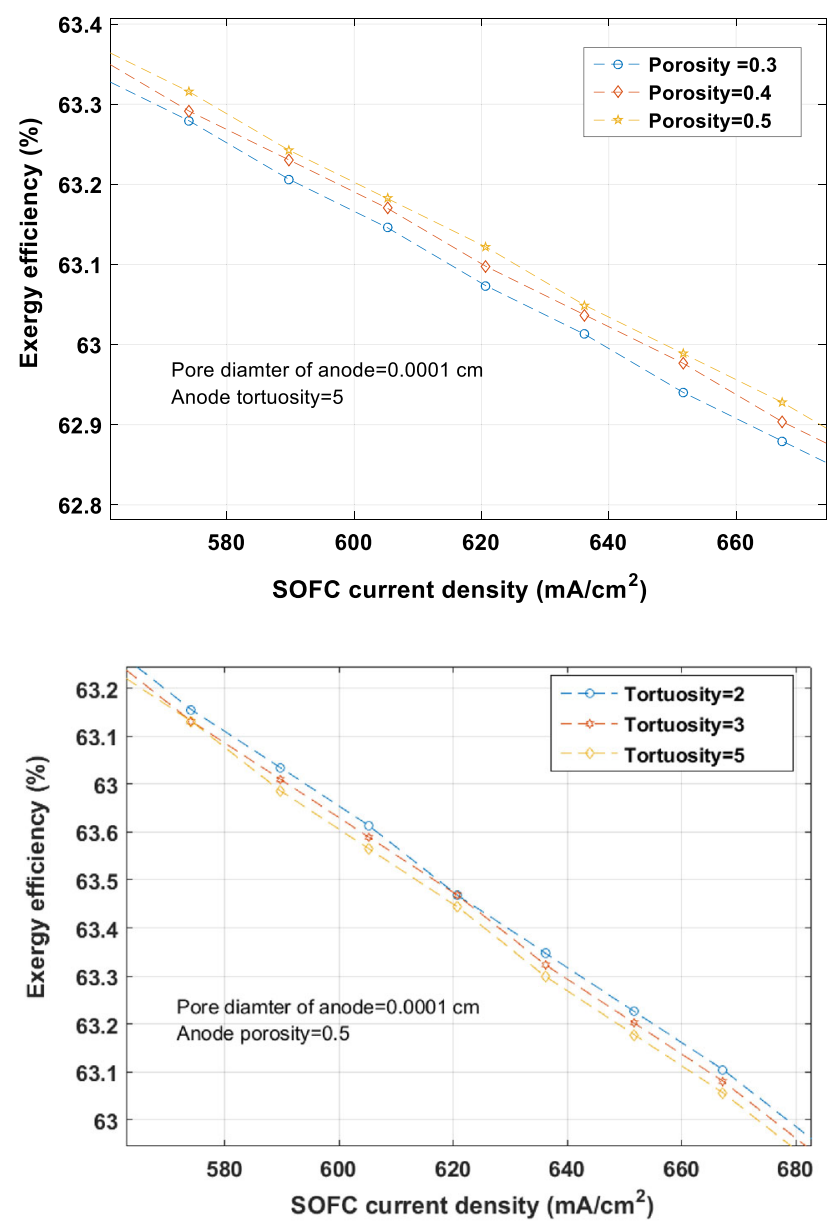

Fig. 4 The effect of current density on the exergy efficiency at different porosity (top) and at different tortuosity (bottom)

exergy efficiency. In Fig. 6 (bottom), the increase of temperature while decreasing the anode tortuosity to 2 reduces the anode pore diffusion coefficient, which caused the anode diffusion overpotential to rise. In Fig. 7, the lowest anode diffusion polarizations were achieved at high anode pressure and temperature of $20 \mathrm{bar}$ and $1300 \mathrm{~K}$, respectively. The increase of anode pressure and operating temperature leads to increase of current-power density [31], which reduces the anode diffusion polarization.

In Fig. 8, the exergy efficiency is analyzed at different operating temperatures. The effect of porosity can barely be seen with the rise of temperature, and this is due to the amount of influence of temperature on the exergy efficiency compared to the effect of anode porosity. As temperature increases, the voltage drops, which is reflected on the exergy efficiency. Also the increase of temperature caused the exergy destruction to increase. This increase of exergy destruction is mostly due to the heat loss based on finite temperature difference, which is reflected on a drop of the exergy efficiency. However, in Fig. 9 different
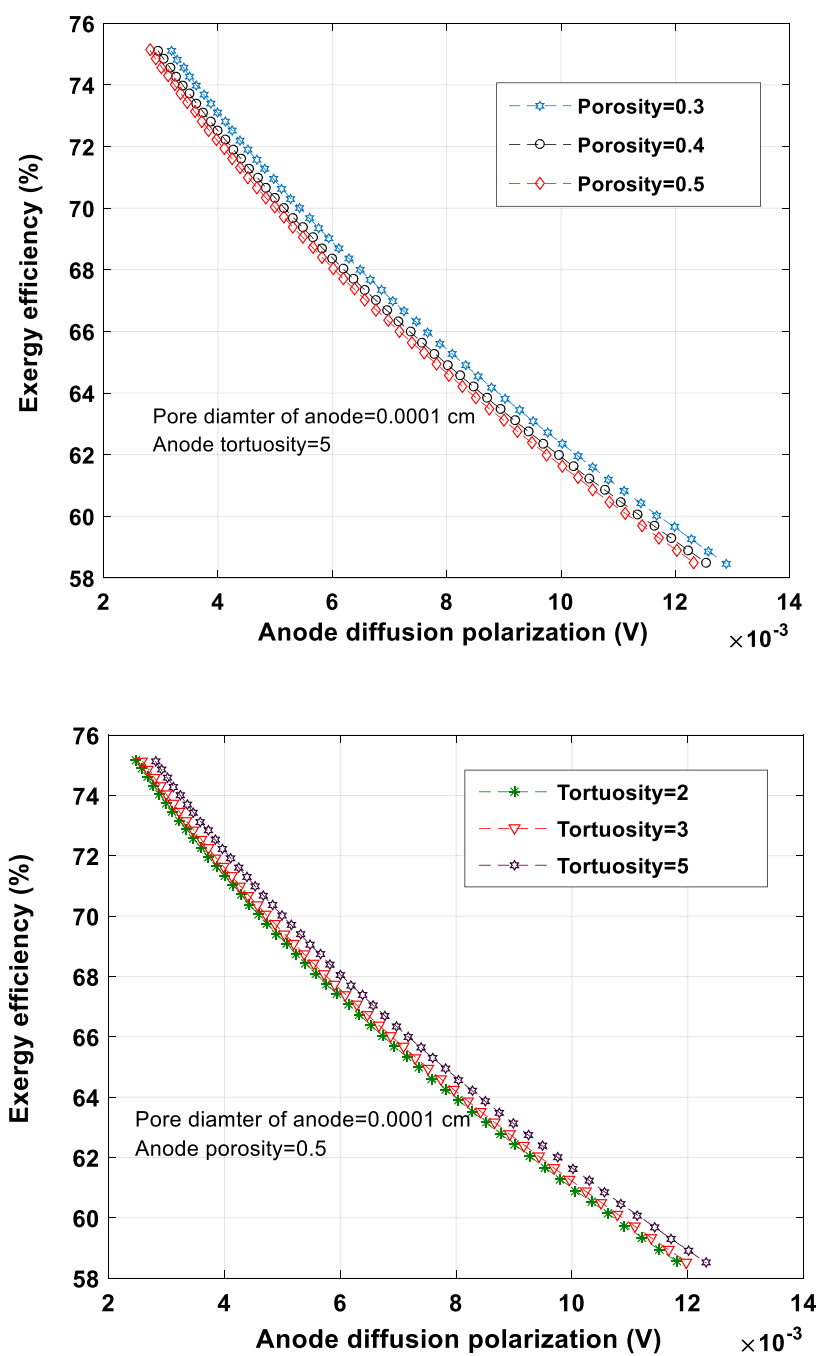

Fig. 5 The effect of anode diffusion polarization on the exergy efficiency at different porosity (top) and at different tortuosity (bottom)

results were obtained by increased the anode pressure, which caused the exergy efficiency to increase; moreover, it is considered a very low effect compared to the effect of temperature; the increase of anode pressure improves the electrochemical reaction of hydrogen at the anode side, which caused the exergy efficiency to partially increase. In order to increase the exergy efficiency of the SOFC by reducing the anode diffusion polarization to its lowest value, it is recommended to decrease the temperature to a range between 1000 and $1300 \mathrm{~K}$ and increase pressure simultaneously above the ambient pressure.

\section{Effect of hydrogen molar fraction}

Figure 10 shows that an increase of the hydrogen molar fraction and current density increases the anode diffusion polarization. The highest polarization was $0.02 \mathrm{~V}$ at the 

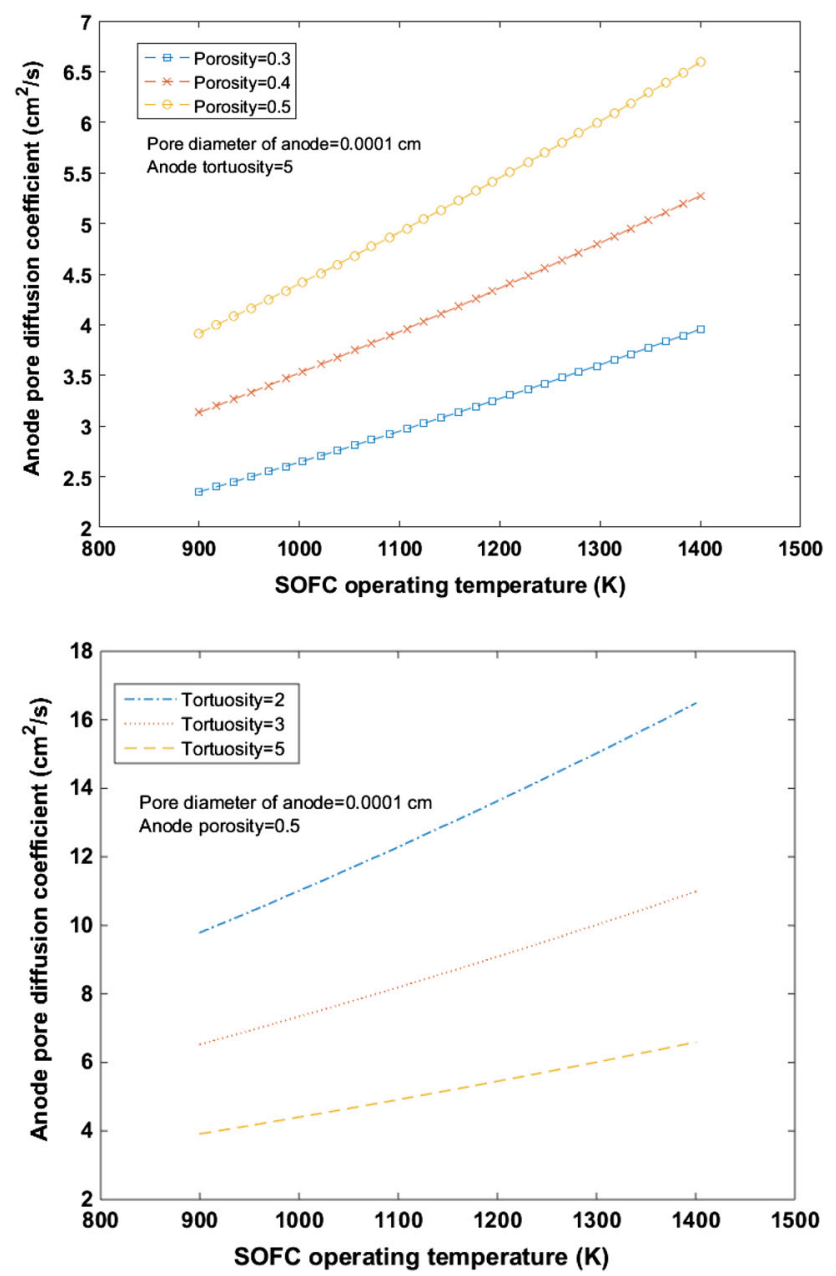

Fig. 6 The effect of SOFC operating temperature on the anode pore diffusion coefficient at different porosity (top) and at different tortuosity (bottom)

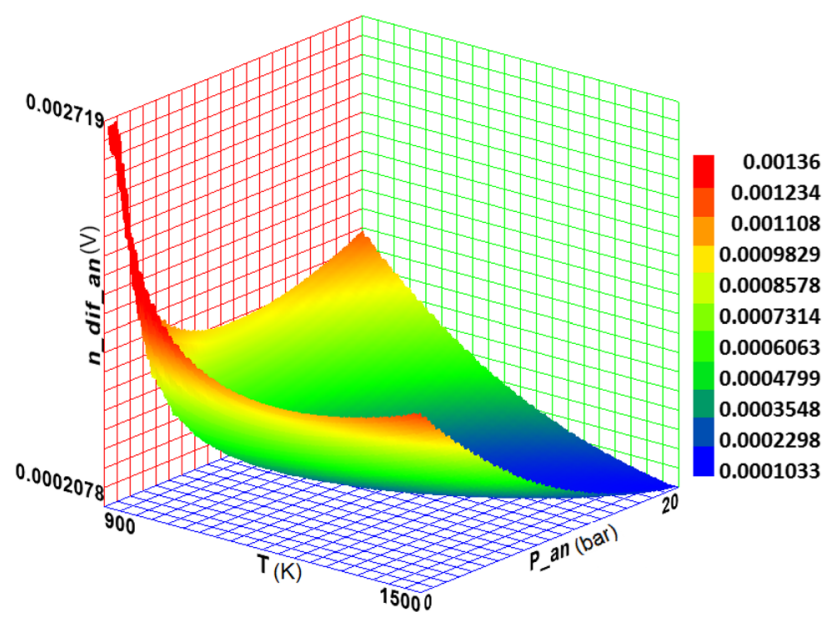

Fig. 7 The effect of anode pressure and temperature on the anode diffusion polarization
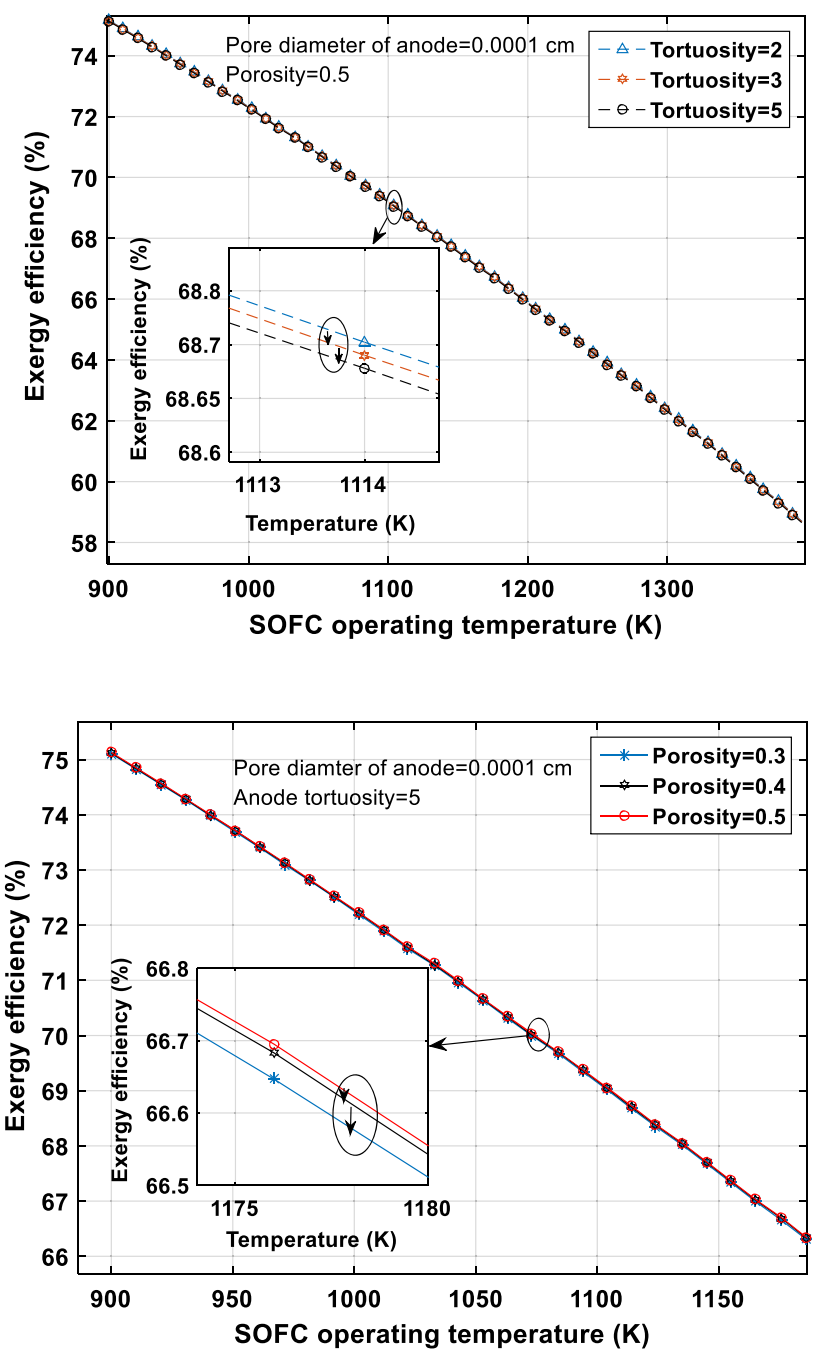

Fig. 8 The effect of temperature on exergy efficiency at different porosity (top) and at different tortuosity (bottom)

hydrogen molar fraction of 0.7 and current density of $810 \mathrm{~mA} / \mathrm{cm}^{2}$, which is considered low-voltage drops compared to the activation and ohmic overpotential [32]. The increase of hydrogen flux at the anode side enhances the electrochemical reaction, which caused the current density to increase and which leads to an increase of the anode diffusion polarization. Because the key parameters affecting the electrochemical reaction rate are hydrogen at the anode side, the high hydrogen concentration at the fuel inlet results in a high reaction rate.

\section{Effect of anode thickness and anodic diffusion path}

Figure 11 (top) shows that decreasing the anode thickness and anodic diffusion path reduces the anode diffusion polarization, which cause an enhancement of the exergy 

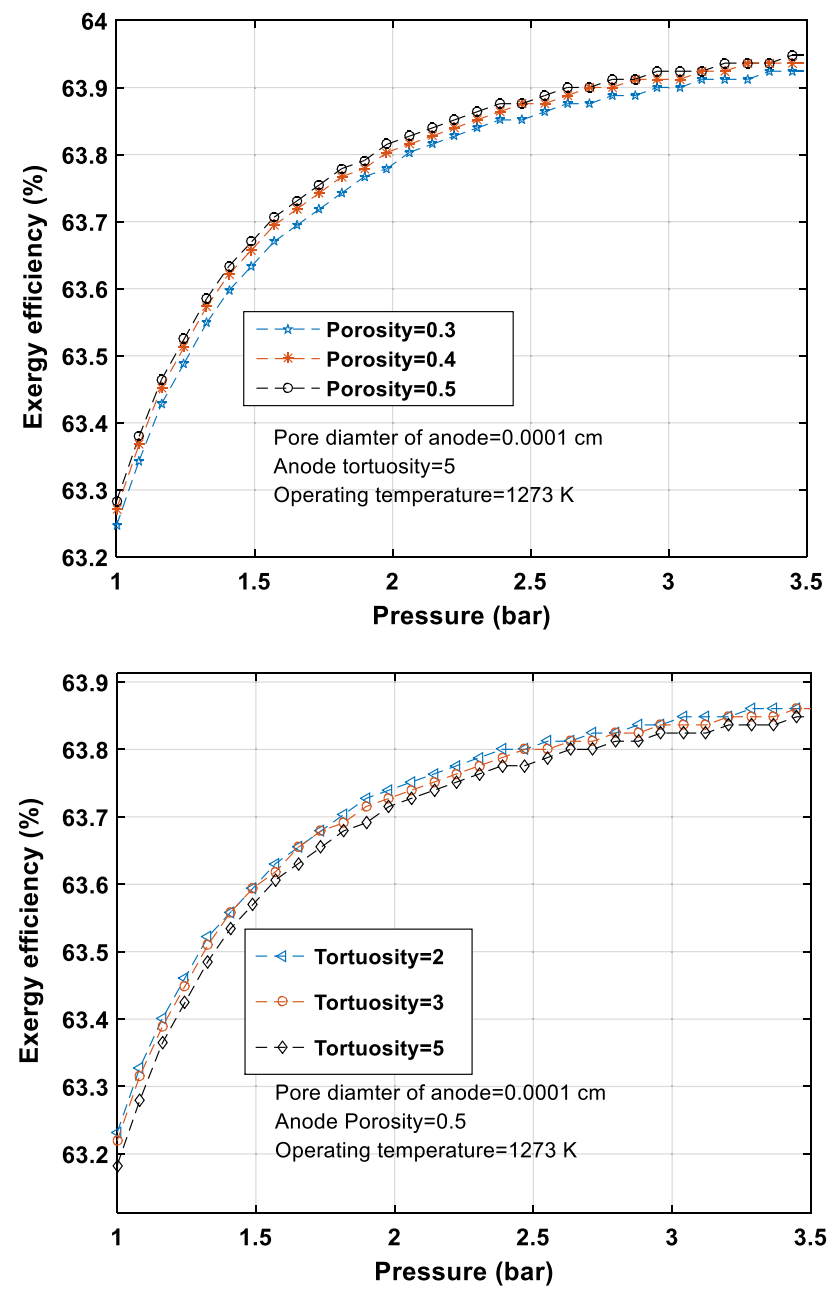

Fig. 9 The effect of anode pressure on exergy efficiency at different anode porosity (top) and at different anode tortuosity (bottom)

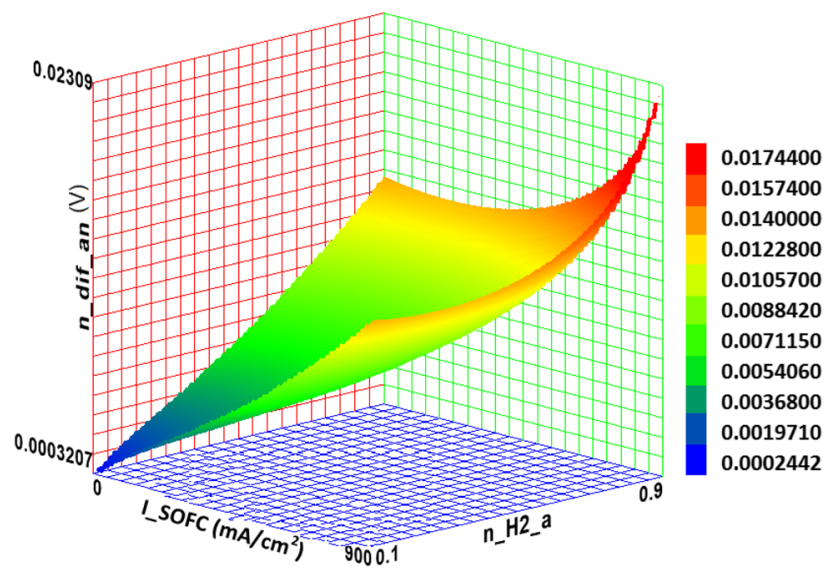

Fig. 10 The effect of hydrogen mole fraction and current density on anode diffusion polarization

efficiency of the SOFC. Therefore, as the thickness rises, the anode gains more reaction spots, which leads to a higher anode diffusion overpotential. The increase of the
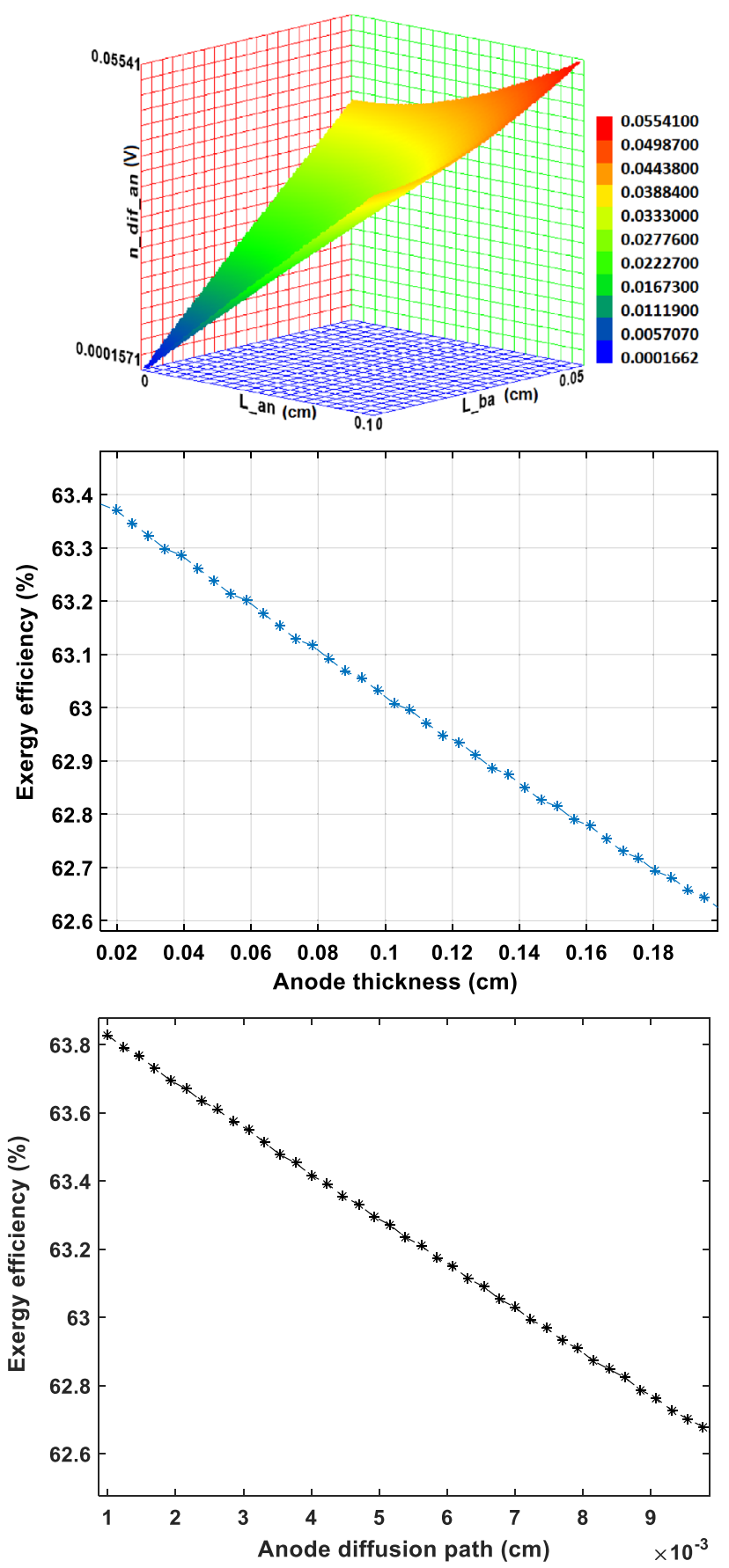

Fig. 11 The effect of anode thickness and anodic diffusion path on the diffusion polarization (top). The effect of anode thickness on exergy efficiency (middle). The effect of anodic diffusion path on exergy efficiency (bottom)

anodic diffusion path length reduces the electrochemical reaction time that occurs at $\mathrm{TPB}$, which is the gas diffusion between the reaction sites and the electrode surface. This increase in the anodic diffusion path leads to an increase in the anode diffusion polarization, which caused the exergy efficiency to drop as shown in Fig. 11 (middle). The 


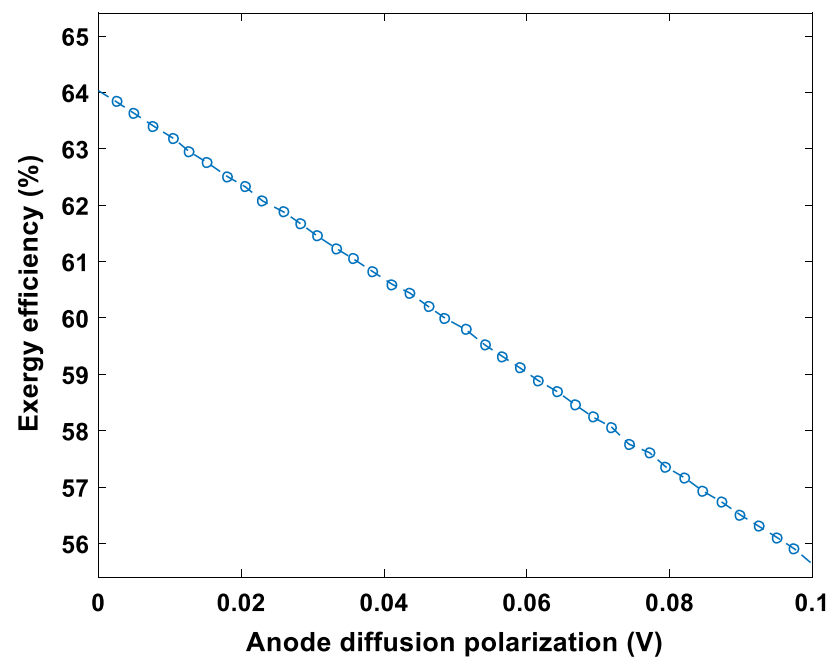

Fig. 12 The effect of anode diffusion polarization on SOFC exergy, energy efficiency

increase of the diffusion path caused a delay in the reaction rate that occurs at the anode side. This increase caused the anode diffusion polarization to increase, which is reflected in a decrease in the exergy efficiency as shown in Fig. 11 (bottom).

Figure 12 shows that the increase of anode diffusion polarization leads to a drop in the voltage of the SOFC, which leads to a decrease in the energy and exergy efficiency. It can be seen that at anode diffusion polarization of $0.005 \mathrm{~V}$, the energy and exergy efficiency are 68 and $52 \%$, respectively.

\section{Conclusions}

The generated model provides a list of controlling parameters that affect the efficiency of the SOFC by reducing the anode diffusion polarization. In this work, a variety of topics have been reviewed, simulated, and discussed to understand the effect of different material parameters and operating conditions on anode diffusion polarization and its effect on the efficiency of the SOFC. Based on the numerical simulations presented in this research, it was demonstrated that the material parameters of the SOFC components such as porosity, tortuosity, and anode thickness have an influence on the exergy efficiency of the SOFC. The use of this numerical model will help and guide researcher to focus on the key parameters that influence the anode diffusion polarization and its effect on energy and exergy efficiency of the SOFC in order to provide a robust design. This model will also reduce the research and developing costs by reducing the research time and the cost of the experiments and equipment. From the above study, it is concluded that to decrease the anode diffusion polarization to the range below $0.001 \mathrm{~V}$ and to enhance the exergy and energy efficiency, the following parameters are recommended:

- Increasing the anode porosity increases the exergy efficiency.

- Decreasing the anode tortuosity increases the exergy efficiency.

- Increasing the pressure above the ambient.

- Increasing the operating temperature by $200 \mathrm{~K}$ or more above the normal operating temperature $\left(\sim 1000{ }^{\circ} \mathrm{C}\right)$.

- Increasing the hydrogen molar fraction enhances the exergy efficiency.

- Decreasing the anode thickness enhances the exergy efficiency.

- Decrease the anodic diffusion path to enhance the exergy efficiency.

Open Access This article is distributed under the terms of the Creative Commons Attribution 4.0 International License (http://crea tivecommons.org/licenses/by/4.0/), which permits unrestricted use, distribution, and reproduction in any medium, provided you give appropriate credit to the original author(s) and the source, provide a link to the Creative Commons license, and indicate if changes were made.

\section{Appendix: Ohmic and activation polarization}

\section{The ohmic polarization}

The ohmic polarization is caused by the ionic resistance of the electrolyte, the electric resistance of the electrode, the cell interconnect, and the contact resistance between mating parts and any other cell components. The aspects that affect the ohmic losses in SOFC are the material conductivity, material thickness, and the contact resistance.

The ohmic resistance can be calculated by the following equation:

$\eta_{\mathrm{ohm}}=R_{\mathrm{ohm}, \mathrm{total}} * i$

where $R_{\text {ohm,total }}$ is total resistance of cathode, anode, electrolyte, and interconnect.

$$
\begin{aligned}
& R_{\text {ohm }, \text { cathode }}=\frac{R T}{2 F^{2}} \sqrt{\frac{\tau}{\left(1-\varepsilon_{\text {cathode }}\right) c_{v} D_{v} a_{s a}\left(\alpha_{f}+\alpha_{b}\right)}} \\
& t_{\text {chem }}=\frac{c_{v}\left(1-\varepsilon_{\text {cathode }}\right)}{r_{o} A_{f} a_{\text {sa }}\left(\alpha_{f}+\alpha_{b}\right)} \\
& R_{\text {gas }}=\frac{1-x}{x} \times \frac{2 L_{b l} R T}{16 F^{2} c D_{A B}} \\
& C_{\text {gas }}=\frac{2 F^{2}\left(1-\varepsilon_{\text {cathode }}\right) c_{v} L}{A R T} .
\end{aligned}
$$


Table 2 Parameters of the ohmic losses in SOFC

\begin{tabular}{llrl}
\hline Components & \multicolumn{2}{l}{ Parameters } & \multirow{2}{*}{ Thickness $(\mathrm{cm})$} \\
\cline { 2 - 3 } & $\alpha(\Omega \mathrm{cm})$ & $\beta(\mathrm{K})$ & \\
\hline Anode & $2.98 \times 10^{-5}$ & 1392 & 0.015 \\
Cathode & $8.11 \times 10^{-5}$ & 600 & 0.2 \\
Electrolyte & $2.94 \times 10-5$ & 10,350 & 0.004 \\
Interconnect & $1.256 \times 10^{-5}$ & 4690 & 0.01 \\
\hline
\end{tabular}

The governing equation and boundaries conditions listed in [33] gives Eq. (41), this equation provides the cathode resistance in terms of diffusion coefficient $D_{v}$, and surface exchange rate in $(\mathrm{cm} / \mathrm{s}), \alpha_{f}$ and $\alpha_{b}$ are constants of the order of unity that depend on the specific mechanism of the exchange reaction.

The governing equation for the electron and ion transport between the anode and cathode are the following:

$i_{\mathrm{el}}=\nabla \cdot\left(-\sigma_{\mathrm{el}} \nabla \emptyset_{\mathrm{el}}\right)$

$i_{\mathrm{io}}=\nabla \cdot\left(-\sigma_{\mathrm{io}} \nabla \emptyset_{\mathrm{io}}\right)$

where $i_{\mathrm{el}}$ and $i_{\mathrm{io}}$ is the ion/electron current density and $\sigma_{\mathrm{el} / \mathrm{io}}$ is the ionic/electronic conductivity. $\emptyset_{\mathrm{el} / \mathrm{io}}$ is the potential for electron conducting materials (io) and (el) for the electrolyte material. All the boundary conditions to solve Eqs. (45) and (46) are listed in Ref. [34].

The ohmic resistance at anode, electrolyte, and interconnect can be calculated by the following equation:

$R_{\text {ohm,anode }}=\rho_{j} \delta_{j}$

where $\rho_{j}$ and $\delta_{j}$ are resistivity and the thickness of the components, respectively. The resistivity of different materials can be expressed as follows:

$\rho_{j}=\alpha_{j} \exp \left(\frac{\beta_{j}}{T}\right)$

where is $\alpha_{j}$ and $\beta_{j}$ are constants specific to material $j$, and $T$ is the operating temperature. Table 2 lists the parameters for the ohmic loss in SOFC [35].

The ionic conductivity of the electrolyte can be calculated by the following equation:

$\varsigma=\frac{l}{R_{\Omega}}$.

\section{Activation polarization}

A buildup of charge occurs between the electrode and electrolyte at the TPB, which caused the activation losses.
The activation polarization (voltage losses at low current density) can be calculated by the following equation:

$\eta_{\text {act }}=\eta_{\text {act }}^{\text {cathode }}+\eta_{\text {act }}^{\text {anode }}$

and $\eta_{\text {act }}^{\text {cathode }}$ and $\eta_{\text {act }}^{\text {anode }}$ are the activation polarization at the cathode and anode, respectively. At the anode, there is a buildup of a positive charge in the surrounding electrolyte and negative charge along the surface of the catalyst. At the cathode, the activation polarization is caused by the buildup of charge that occurs across the TPB at electrolyteelectrode interface. The $\eta_{\text {act }}^{\text {cathode }}$ and $\eta_{\text {act }}^{\text {anode }}$ can be calculated by the following equations:

$i=i_{o}\left\{\exp \left(\beta \frac{n F \eta_{\text {act }}}{R T}\right)-\exp \left[-(1-\beta) \frac{n F \eta_{\text {act }}}{R T}\right]\right\}$

$i_{\text {o,an }}=\gamma_{\text {an }}\left(\frac{p_{\mathrm{H}_{2}}}{p_{\mathrm{amb}}}\right)\left(\frac{p_{\mathrm{H}_{2} \mathrm{O}}}{P_{\mathrm{amb}}}\right)^{m} \exp \left(-\frac{E_{\mathrm{act}, \mathrm{an}}}{R T}\right) A$

$i_{\text {o,cat }}=\gamma_{\text {cat }}\left(\frac{p_{\mathrm{O}_{2}}}{p_{\text {amb }}}\right)^{0.25} \exp \left(-\frac{E_{\text {act,cat }}}{R T}\right) A$.

The parameters $\gamma_{\mathrm{an}}, \gamma_{\mathrm{cat}}, m, E_{\mathrm{act}, \mathrm{cat}}$, and $E_{\mathrm{act}, \text { an }}$ are listed in Table 3 below.

The exchange current density can also be calculated with the following equation using the interface conductivity and transfer coefficient

$I_{o}=\frac{\sigma_{o} R T}{\left(2+\alpha_{\text {act }}\right) F}$

where $\alpha$ is the transfer coefficient and $\sigma_{o}$ is the interface conductivity, which can be calculated by the following equation:

$\sigma_{o}+\beta \cdot \exp \left(\frac{-\Delta G_{\mathrm{act}}}{R T}\right) P_{\mathrm{O}_{2}, B}^{y}$

where $\gamma$ is the reaction order, $\beta$ is a constant, $\Delta G_{\text {act }}$ is the

Table 3 Activation polarization parameters

Activation polarization parameters

Activation of energy anode, $E_{\text {act,an }}$ $110(\mathrm{~kJ} / \mathrm{mol} \mathrm{k})$

Activation of energy cathode, $E_{\text {act,cat }}$ $120(\mathrm{~kJ} / \mathrm{mol} \mathrm{k})$

Pre-exponential coefficient for anode, $\gamma_{\mathrm{an}}$ $0.7 \times 10^{-9}\left(\mathrm{~mA} / \mathrm{cm}^{2}\right)$

Pre-exponential coefficient for cathode $\left(\mathrm{mA} / \quad 0.7 \times 10^{-9}\left(\mathrm{~mA} / \mathrm{cm}^{2}\right)\right.$ $\left.\mathrm{cm}^{2}\right), \gamma_{\text {cat }}$

Coefficient, $m$

Table 4 Coefficients of the activation polarization

\begin{tabular}{lllll}
\hline Position & $\alpha$ & $\beta$ & $\gamma$ & $\Delta G_{\text {act }}(\mathrm{kJ} / \mathrm{mol})$ \\
\hline $\begin{array}{l}\text { Fuel } \\
\text { electrode }\end{array}$ & 1 & 107.79 & 0.133 & 120 \\
Air electrode & 2 & 106.02 & 0.5 & 130 \\
\hline
\end{tabular}


activation energy, and $P_{\mathrm{O}_{2}, B}^{\gamma}$ is the oxygen pressure, which can be calculated by the following equation:

$P_{\mathrm{O}_{2}, B}^{\gamma}=\left(\frac{P_{\mathrm{H}_{2} \mathrm{O}, B}}{K_{\mathrm{OX}} P_{\mathrm{H}_{2}, B}}\right)^{2}$

where $K_{\mathrm{ox}}$ is equilibrium constant of the oxidation of hydrogen. Table 3 below shows the coefficient parameters of the activation polarization:

The input parameters of the activation polarization are listed in Tables 3 and 4.

\section{References}

1. Blomen, L.J.M.J., Mugerwa, M.N.: Fuel Cell Systems, 3rd edn. Springer: Springer Science \& Business Media, New York (1993)

2. Casanova, A.: A consortium approach to commercialized Westinghouse solid oxide fuel cell technology. J. Power Sources 71(1-2), 65-70 (1998). doi:10.1016/S0378-7753(97)02757-2

3. Dincer, I., Midilli, A., Kucuk, H.: Progress in Exergy, Energy, and the Environment. Springer, New York (2014)

4. Shimada, H., Suzuki, T., Yamaguchi, T., Sumi, H., Hamamoto, K., Fujishiro, Y.: Challenge for lowering concentration polarization in solid oxide fuel cells. J. Power Sources 302, 53-60 (2016). doi:10.1016/j.jpowsour.2015.10.024

5. Komatsu, Y., Brus, G., Kimijima, S., Szmyd, J.S.: The effect of overpotentials on the transient response of the $300 \mathrm{~W}$ SOFC cell stack voltage. Appl. Energy 115, 352-359 (2014). doi:10.1016/j. apenergy.2013.11.017

6. Shabana, P.S.S., Andanastuti, M., Mahendra, R.S.: A review on the selection of anode materials for solid-oxide fuel cells. Renew. Sustain. Energy Rev. 51, 1-8 (2015). doi:10.1016/j.rser.2015.05. 069

7. Hagen, A., Rasmussen, J.F.B., Thydén, K.: Durability of solid oxide fuel cells using sulfur containing fuels. J. Power Sources 196(17), 7271-7276 (2011). doi:10.1016/j.jpowsour.2011.02. 053

8. Cheng, Z., Wang, J., Choi, Y., Yang, L., Lin, M.C., Liu, M.: From Ni-YSZ to sulfur-tolerant anode materials for SOFCs: electrochemical behavior, in situ characterization, modeling, and future perspectives. Energy Environ. Sci. 11, 4380-4409 (2011). doi:10.1039/C1EE01758F

9. Yoshizumi, T., Taniguchi, S., Shiratori, Y., Sasaki, K.: Sulfur poisoning of SOFCs: voltage oscillation and Ni oxidation fuel cells, electrolyzers, and energy conversion. J. Electrochem. Soc. 159(11), F693-F701 (2012). doi:10.1149/2.032211jes

10. Zhang, X., Chen, J.: Performance analysis and parametric optimum criteria of a class of irreversible fuel cell/heat engine hybrid systems. Int. J. Hydrog. Energy 35(1), 284-293 (2010)

11. Xianguo, L.: Principles of Fuel Cells, p. 479. Taylor \& Francis, New York (2006)

12. Suwanwarangkul, R., Croiset, E., Pritzker, M.D., Fowler, M.W., Douglas, P.L., Entchev, E.: Modelling of a cathode-supported tubular solid oxide fuel cell operating with biomass-derived synthesis gas. J. Power Sources 166(2), 386-399 (2007). doi:10. 1016/j.jpowsour.2006.12.096

13. Suwanwarangkul, R., Croiset, E., Entchev, E., Charojrochkul, S., Pritzker, M.D., Fowler, M.W., Douglas, P.L., Chewathanakup, S., Mahaudom, H.: Experimental and modeling study of solid oxide fuel cell operating with syngas fuel. J. Power Sources 161(1), 308-322 (2006). doi:10.1016/j.jpowsour.2006.03.080

14. Suwanwarangkul, R., Croiset, E., Pritzker, M.D., Fowler, M.W., Douglas, P.L., Entchev, E.: Mechanistic modelling of a cathodesupported tubular solid oxide fuel cell. J. Power Sources 154(1), 74-85 (2006). doi:10.1016/j.jpowsour.2005.03.197

15. Bruce, E., Poling, J., Prausnitz, M., O'Connell, J.P.: Properties of Gases and Liquids, 5th edn. McGraw-Hill, Maidenheach (2001). doi:10.1036/0070116822

16. Turner, J.C.R.: On the formulation of the diffusion coefficient in isothermal binary systems. Chem. Eng. Sci. 30(1), 151-154 (1975). doi:10.1016/0009-2509(75)85126-8

17. Akkaya, A.V.: Electrochemical model for performance analysis of a tubular SOFC. Int. J. Energy Res. 31, 79-98 (2006). doi:10. 1002/er.1238

18. Satterfield, A.: Mass Transfer in Heterogeneous Catalysis, p. 43. MIT, Cambridge (1970)

19. El-Emam, R.S, Dincer, I., Naterer, G.F.: Energy and exergy analyses of an integrated SOFC and coal gasification system. Int. J. Hydrog. Energy, 37(2), 1689-1697 (2012). ISSN 0360-3199. doi:10.1016/j.ijhydene.2011.09.139

20. Chitsaz, A., Mohammad, S., Mahmoudi, S., Rosen, M.A.: Greenhouse gas emission and exergy analyses of an integrated trigeneration system driven by a solid oxide fuel cell. Appl. Therm. Eng. 86, 81-90 (2015). doi:10.1016/j.applthermaleng. 2015.04.040

21. Bejan, A., Tsatsaronis, G., Moran, M.: Thermal Design and Optimization. Wiley, New York (1996)

22. Ghosh, S., De, S.: Exergy analysis of a cogeneration plant using coal gasification and solid oxide fuel cell. Int. J. Energy Res. 30, 647-658 (2006). doi:10.1002/er.1171

23. Colpan, C.O., Dincer, I., Hamdullahpur, F.: A review on macrolevel modeling of planar solid oxide fuel cells. Int. J. Energy Res. 32, 336-355 (2008). doi:10.1002/er.1363

24. Xiang, J.Y., Calì, M., Santarelli, M.: Calculation for physical and chemical exergy of flows in systems elaborating mixed-phase flows and a case study in an IRSOFC plant. Int. J. Energy Res. 28, 101-115 (2004). doi:10.1002/er.953

25. Hosseini, M., Dincer, I., Ahmadi, P., Avval, H.B., Ziaasharhagh, M.: Thermodynamic modelling of an integrated solid oxide fuel cell and micro gas turbine system for desalination purposes. Int. J. Energy Res. 37, 426-434 (2013). doi:10.1002/er.194

26. Akkaya, A.V., Sahin, B.: A study on performance of solid oxide fuel cell-organic Rankine cycle combined system. Int. J. Energy Res. 33, 553-564 (2009). doi:10.1002/er.1490

27. Bessette, N.: Modeling and simulation for solid oxide fuel cell power systems, PhD thesis, Georgia Institute of Technology, Atlanta (1994)

28. Anon. Fuel Cell Handbook, 5th edn. US Department of Energy (2000)

29. Incropera, F., Dewitt, D.: Fundamentals of Heat and Mass Transfer, 4th edn. Wiley, New York (1996)

30. Ren, C., Liu, T., Maturavongsadit, P., Luckanagul, J.A., Chen, F.: Effect of PEG additive on anode microstructure and cell performance of anode-supported MT-SOFCs fabricated by phase inversion method. J. Power Sources 279, 774-780 (2015). doi:10. 1016/j.jpowsour.2014.12.140

31. Larry, A., Chick, O., Marina, A., Coyle, C.A., Thomsen, EdC: Effects of temperature and pressure on the performance of a solid oxide fuel cell running on steam reformate of kerosene. J. Power Sources 236, 341-349 (2013). doi:10.1016/j.jpowsour.2012.11. 136

32. Ranjbar, F., Chitsaz, A., Mahmoudi, S.M.S., Khalilarya, S., Rosen, M.A.: Energy and exergy assessments of a novel trigeneration system based on a solid oxide fuel cell. Energy Convers. 
Manag. 87, 318-327 (2014). doi:10.1016/j.enconman.2014.07. 014

33. Adler, S.B., Lane, J.A., Steele, B.C.H.: Electrode kinetics of porous mixed-conducting oxygen electrodes. J. Electrochem. Soc. 143(11), 3554-3564 (1996). doi:10.1149/1.1837252

34. Andersson, M., Yuan, J., Sundén, B.: SOFC modeling considering hydrogen and carbon monoxide as electrochemical reactants.
J. Power Sources 232, 42-54 (2013). doi:10.1016/j.jpowsour. 2012.12.122

35. Chan, S.H., Low, C.F., Ding, O.L.: Energy and exergy analysis of simple solid-oxide fuel-cell power systems. J. Power Sources 103(2), 188-200 (2002). doi:10.1016/S0378-7753(01)00842-4 